\title{
Corporate strategic planning as practised in South African organizations ${ }^{*}$
}

\author{
T.L. Woodburn \\ Grey Mann Associates (Pty) Limited, Johannesburg
}

This article summarizes the findings of a research survey of the corporate strategic planning practices of over 500 South African based organizations.

The major portion of the survey is concerned with the following three facets:

(i) Those environmental and organizational characteristics which influence the extent and nature of the planning processes.

(ii) Influences on the need for, and use of, corporate objectives.

(iii) The types of strategies, and methods of formulation, used by different organizations operating under different conditions

Several ancillary areas are also examined, namely:

(a) specific organizational facets and their planning relationships;

(b) administrative facets of planning;

(c) managerial involvement and the influence on planning departments; and

(d) interest group influence on the formulation of objectives.

S. Afr. J. Bus. Mgmt. 1984, 15: $21-33$

Hierdie artikel is 'n opsomming van die bevindinge van 'n opname oor korporatiewe strategiese beplanningsprosesse wat in meer as 500 Suid Afrikaanse organisasies onderneem is.

Die opname handel hoofsaaklik oor die volgende drie fasette:

(i) Die organisatoriese en omgewingseienskappe wat die omvang en aard van die beplanningsprosesse beinvloed.

(ii) Faktore wat die behoefte aan, en gebruik van, korporatiewe doelwitte beinvloed.

(iii) Die tipe strategieë, en metodes van formulering, wat deur verskeie organisasies onder verskillende omstandighede gebruik word.

Bykomstige gebiede waarna gekyk word, is:

(a) spesifieke organisasie-eienskappe en hulle beplanningsrelasies;

(b) administratiewe fasette van beplanning;

(c) bestuursbetrokkenheid en die invloed daarvan op beplanningsafdelings; en

(d) invloed van belangegroepe op die formulering van doelwitte

S.Afr. Tydskr. Bedryfsl. 1984, 15: $21-33$

- The substance of this article is based on research undertaken by Dr T.L. Wood. burn, under the supervision of Drs D.C. Limerick and C.L. Suzman, and approved for the Ph.D degree by the Faculty of Commerce. University of the Witwatersrand, Johannesburg).

Dr T.L. Woodburn

Grey Mann Associates (Pty) Ltd., P.O. Box 1153,

Johannesburg,

2000 Republic of South Africa

Accepted October 1983

\section{Research objectives and methodology}

From gaps observed in literature on the state of the art of corporate planning the following broad areas of interest were selected for empirical investigation.

(a) Those environmental and organizational characteristics which influence the extent and nature of the planning process particularly in South Africa.

(b) Influences on the need for, and use of, corporate objectives.

(c) The types of strategies, and methods of formulation, used by different organizations operating under different conditions.

With the aid of supporting theory and practice, each of these broad areas were developed into propositions which in turn were amplified into testable hypotheses and a methodology developed for their operationalization. In addition, a number of ancillary areas were identified for less rigorous examination. Having established the broad research objectives above, it was necessary to consider the research strategy that would be followed. After examining the suitability of the available repertoire of procedures, a large sample mail questionnaire survey was selected.

To facilitate the format design and subsequent reduction and analysis of data contained in the questionnaire, use was made of the facilities offered by the following two powerful computer packages:

(i) OSIRIS (An integrated collection of computer programs for the management of social science data), and

(ii) SPSS (Statistical Package for the Social Sciences).

Due to the complexity of the questionnaire, use was made of a two-phase pilot study to eliminate problem areas prior to the finalization of its design. A total of 3775 questionnaires were finally sent out to a wide selection of public and private organizations operating in South Africa and of these, 518 questionnaires were completed and returned.

\section{Data reduction and analysis}

The first phase of analysis consisted of determining frequency distributions and histogram representations of all variables on the master file so as to confirm the adequacy of the samples of data collected. This print-out then formed a reference document for subsequent analyses. Simple classifactory procedures for the categorization of organizations proved ineffective. This necessitated a more advanced approach which involved factor analysing the measures of each organization's centralizaiton, formalization and specialization. The factor scores generated were then fed into a cluster analysis program and 
a series of clusters produced for various organizational decision structures. A graphical plot of the criterion values for each cluster group indicated initially that between three and five clusters would yield a good representation of organizational types. In addition to its use for the categorization of organizations, cluster analysis was also used to classify the operational environments. Discriminant analysis was finally used to give an indication of the separation of the groups formed by classifications derived from the clustering procedures. In both cases of the organizational and environmental clusters, the discriminant analyses indicated clear separations between the clustered groups.

The organizational and environmental clusters derived earlier were used as the basis for extensive statistical testing of the research hypotheses. Correlation analysis was first used to measure the linear relationship between variables so as to obtain a summary statistic of their strength of association. The significant correlations were then used as a guide for relating the physical parameters and planning involvement to the organizational and environmental clusters. An analysis of variance of all dependent variables with each cluster indicated high statistical significance for the physical parameters such as age, number of employees, turnover and assets but no significance for variables such as maturity of the organization, growth rate or profitability. Mean values of the physical parameters in each cluster group revealed a continuum ranging from the smallest and youngest organizations to the largest and oldest. Expanding the cluster groups from three to six, clearly indicated the changing profiles of organizations as they moved from one cluster to the next in their corporate growth. The three and five cluster solutions clearly showed how organizations moved from a decentralized decision structure to a centralized structure and then back to a decentralized structure as they moved along the continuum in their corporate growth cycle. The additional details brought out in the four and six cluster solutions showed alternative or intermediate decision structures which organizations assume to suit their particular characteristics and requirements during their corporate growth. The various cluster members forming this organizational continuum were also subjected to analyses of variance for scores of involvement in corporate planning. High statistically significant results from this analysis revealed that as the size and complexity of the organization increased, so also did its degree of involvement and formality of its planning activities increase.

Characteristics of the operational environments were determined by subjecting each of the two to five clusters previously selected to one-way analyses of variances. No statistical significance was found across any of the clusters for any of the physical parameters of age, size, turnover or assets. High statistical significances were however, found across the two and four clusters for the degrees of involvement in each of the various facets and total process of corporate planning. The degree of formality of each of the facets and total process of corporate planning was statistically significant for most of the items across the two cluster solution and to a lesser extent across the four cluster solution. Mean values for degrees of involvement in planning for each of the two and four cluster environments, indicated that the degrees of involvement increased as the complexity and uncertainty of the operational environment increased.

To determine the joint effects of the organizational and environmental clusters on the degree of an organization's involvement in corporate planning, use was made of a two-way analysis of variance and covariance. Jointly the covariates of age, number of employees, assets and turnover were found to be significant, but only turnover was significant on its own. This analysis further showed that after the extraneous variations caused by the covariates had been removed, the joint main effects of the organizational and environmental clusters on planning involvement were highly significant, but individually only the organizational clusters were significant, with the environmental clusters losing significance. Finally, the two-way interaction effect between the organizational and environmental clusters were found not to be significant. These results revealed a number of important implications. Firstly, turnover emerged as a strong measure of an organization's size since it cut across other indicators such as capital and labour intensity. Organizational size in turn had a strong bearing on the organization's degree of involvement in the overall corporate planning process. When considered separately, organizational and environmental cluster categorizations were significantly related to the degree of an organization's involvement in planning, but when considered together, the organizational characteristics emerged considerably stronger with their influence on planning than did the degree of environmental uncertainty. Finally, the organizational characteristics were not dictated by the degree of environmental uncertainty, neither did the organizational characteristics influence the degree of uncertainty of the environment. In a discriminant analysis of planning involvement, environmental factors proved to be insufficiently discriminatory to enter into the step-by-step process.

From the various analyses conducted, it was concluded that, while environmental uncertainty did play a part in determining the degree of an organization's involvement in the corporate planning process, the complexity of the organization itself played a stronger and more dominant role in dictating the degree of involvement. Planning, in the context of this research, appeared to be primarily a powerful internal integrator of complex organizations, and only secondarily a mechanism or device with which to cope with external environmental uncertainty. This finding highlights a concept previously ignored in the planning literature with the exception of the article by Athreya on 'Planning as Integration' (Lorsch \& Lawrence, 1970).

\section{Survey results and the hypotheses}

As was expected from the philosophy of Tukey (1969), the actual research results indicated differences from those suggested by the hypotheses which had been established to provide direction for the research. The findings obtained from the survey research suggested that it would be necessary to substantially modify the original hypotheses so as to more accurately represent the situation expected in practice. The reasons for the modifications which were necessary, are summarized below, together with the new set of more representative propositions which were derived.

The first hypothesis was concerned with those environmental and organizational characteristics which influenced the extent and nature of the planning processes used by the organizations. In this regard, the oscillating administrative centralization dimension which was found in the five cluster organizational solution seemed to suggest that, as organizations grow in size and complexity over a period of time, they enter growth phases in which a need arises to centralize decisions to integrate the organization. Once stability is achieved, decisions then tend to become decentralized until growth and further complexity again demand increased centralization to integrate the more diverse organization. In the case of vertically integrated 
organizations, the integrative needs were clearly strategic centralization, rather than administrative centralization, whereas in the case of multiple interdependent companies, strong administrative centralization was required. The statistically significant findings led to the construction of the following basic proposition which embodies organizational structure.

1.1 Organizations tend to require different internal structural characteristics which may be portrayed along a continuum representing, at the one end, young, small, simple organizations through to older, large, complex organizations, at the other end of the continuum. As the size and complexity of organizations increase, their characteristics change so as to meet their more complex differentiative or integrative needs.

In addition to changing the characteristics of the internal decision structure along the continuum to achieve integration, organizations also increased their involvement in planning as their size and complexity increased. This significant finding suggested that planning was an important integrative device which led to the following basic proposition embodying both organizational structure and planning involvement.

1.2 As organizations increase in size and complexity, they tend to increase their use of corporate planning as an integrative device.

Insofar as the environment was concerned, it was found that strong integrative needs were required by organizations operating in the more diverse heterogeneous environments. It was further found significant that the larger more complex organizations tended to operate in the heterogeneous part of a dichotomized environment which led to the formulation of the following basic proposition relating the structure of organizations to their operational environment.

1.3 As organizations increase in size, and as their structures become more complex, they tend to operate in the more complex heterogeneous part of a dichotomized environment.

Finally, it was significantly found that as the operational environment became more complex, organizations tended to increase their involvement in corporate planning which led to the following basic proposition.

1.4 Organizations which operate in increasingly complex operational environments tend to increase their degree of involvement in corporate planning.

The four basic propositions which were developed, were then combined into the following single overall summary proposition, which provided a more representative picture than that originally suggested by the first hypothesis.

t. The greater the differentiation and environmental uncertainty caused by growth, diversification and organizational complexity, the greater become the integrative needs provided by the range of facilities of corporate planning.

The second hypothesis was concerned with the influences on the need for, and use of, corporate objectives. In this regard, the general formulation of corporate objectives and goals by organizations was found to increase along the continuum and then peak for the strongly centralized cluster before decreasing for the decentralized cluster at the end of the continuum. The strong integrative needs of this centralized cluster were again demonstrated in the high need to formulate objectives and goals. The uses of all three classes of specific objectives were strongly evident in the administratively centralized cluster organizations as well as the large decentralized cluster indicating the integrative function being fulfilled by these objectives. The use of 'participant' objectives as 'people integrators' was found in the larger organizations whereas strategic objectives appeared to be used as supportive 'structural integrators' in centralized organizations. It was further found that a higher percentage of organizations operating in heterogeneous environments formulated objectives, goals and targets than those operating in the simple homogeneous environment. In particular, a greater increase in the use of strategic objectives was found in the more complex environment. From the statistically significant findings, it was possible to develop the following summary propositions, which provided a more representative picture of the formulation of corporate objectives than that originally suggested by the second hypothesis.

2.1 As the size and complexity of organizations increase they tend to make increasing use of the three classes of corporate objectives and of goals.

2.2 Participant objectives tend to be used as people integrators in large organizations.

2.3 Performance and strategic objectives tend to be used extensively by the larger more complex organizations.

2.4 As the operational environment becomes more complex and uncertain, organizations tend to increase their use of detailed goals.

In addition to the above statistically significant relationships, the following relationships were suggested by the survey data but found to be statistically independent:

2.5 Organizations operating in the complex heterogeneous environment tend to make a greater use of the three classes of objectives

2.6 Strategic objectives tend to be used as both structural and environmental integrators.

The third and final hypothesis was concerned with the types of strategies and methods of formulation used by different organizations operating under different conditions. In this regard, the survey data suggested that the entrepreneurial mode of strategy formulation steadily decreased as the size and complexity of organizations increased. Likewise, use of the adaptive mode, which was the most used mode in the smaller organizations, also decreased as the size and complexity of the organizations increased. In contrast, use of the planning mode of strategy formulation steadily increased as the size and complexity of the organizations increased. Strategy was again found to play a strong integrative role in the administratively centrallized clusters as well as was evident by the preparation of portfolios of strategic alternatives. A high percentage of small organizations were found to use proactive strategies and the use thereof was then found to decrease as the size and complexity of the organizations increased. In contrast, reactive strategies were found to progressively decrease in use as the size and complexity of the organizations increased. Insofar as the environment was concerned, a higher percentage of organizations operating in the dynamic/ heterogeneous environment were found to formulate strategies and portfolios of strategic alternatives than those operating in the more stable/homogeneous environment. It was further found that the entrepreneurial mode of strategy formulation tended to be used in the more stable/homogeneous environments, while the adaptive and planning modes tended to be used in the more dynamic/heterogeneous environments. A greater use was made of both proactive and reactive strategies in the dynamic/heterogeneous than in the stable/homogeneous environment. As organizations increased in size and complexity along the continuum, they swung from a predominant use of the entrepreneurial mode in dynamic/heterogeneous environments to a predominance in the stable/homogeneous environment. Similarly, from 
a predominant use of the adaptive and planning modes in stable/homogeneous environments, they swung to a predominant use of these modes in the dynamic/heterogeneous environment as their size and complexity increased along the continuum. From those findings above, which were statistically significant, it was possible to develop the following summary propositions for the formulation of strategy which better represented the practical situation than that originally suggested by the third hypothesis.

3.1 As organizations increase in size and complexity they tend to make:

- increasing use of reactive strategies and the planning mode of strategy formulation, and

- decreasing use of the entrepreneurial mode of strategy formulation.

3.2 Organizations tend to make increasing use of strategy as the operational environment becomes more complex.

3.3 Proactive strategies tend to be used by organizations operating in the more heterogeneous part of a dichotomized environment.

In addition to those significant relationships above, the survey data also suggested the following statistically independent relationships.

3.4 As organizations increase in size and complexity they tend to make decreasing use of proactive strategies and the adaptive mode of strategy formulation.

3.5 Organizations tend to make increasing use of portfolios of strategic alternatives as the operational environment becomes more complex.

3.6 In general, organizations tend to formulate strategies using the:

- entrepreneurial mode when operating in stable/homogeneous environments, and

- adaptive or planning modes when operating in dyna$\mathrm{mic} /$ heterogeneous environments.

3.7 (a) Young small organizations at the lower end of the organizational continuum tend to formulate strategies using the

- entrepreneurial mode when operating in dynamic/heterogeneous environments, and

- adaptive or planning modes when operating in stable/homogeneous environments.

(b) Older large organizations at the upper end of the organizational continuum tend to formulate strategies using the

- entrepreneurial mode when operating in stable/homogeneous environments, and

- adaptive or planning modes when operating in dynamic/heterogeneous environments.

\section{Ancillary findings from the survey}

Several ancillary and somewhat less rigorous analyses were also undertaken with the survey data. Four distinct ancillary areas of interest were examined; each embodying a number of specific and highly directed avenues of research. A number of the relationships tested proved to be statistically significant, while others, although suggested by the data, were not statistically significant. Some of the more important results obtained from these various ancillary analyses are summarized below.

\section{Specific organizational facets and their planning
relationships}

To undertake this analysis, a series of contingency tables wete produced from cross-tabulations between the various organizational facets and planning involvement. The first of these tables determined the percentage of each organizational facet, which undertook the various components of planning. The results of this analysis are reproduced in Table 1. It should be noted that the numbers in this table represent specific percentages of organizations undertaking a particular activity and do not add up either vertically or horizontally to 100,0 . A particular percentage was obtained by dividing the number of organizations undertaking that particular planning component by the total number of organizations responding to that row item. A second table, in support of the first was also produced. This table determined, for the same organizational facets, their degrees of involvement in the overall corporate planning process. The four-point scale of degrees of involvement in corporate planning which was developed earlier was used for this tabulation. The results of this analysis are reproduced in Table 2. It should be noted that in this table the numbers shown represent the percentages of organizations involved in the overall process but broken down into four groups of degree. These percentages add horizontally to 100,0 subject to rounding off errors. A number of interesting conclusions can be drawn from the information presented in these tables.

\section{Country of origin influence}

Although companies with origins from around the world responded, a predominance of responses came from South African (315), British (98) and American (46) origins. It can be clearly seen in Table 1, that in all areas of corporate planning, more companies with American origins undertook these activities than the others. This was closely followed by companies of British origin and finally companies of South African origin. The chi-square for the relationship between country of origin and involvement in the overall corporate planning process is significant at the 0,050 level. The greatest area of lag between the South African and British companies was for 'strategic' and 'long range planning'. Both the British and American companies were well ahead in these areas. The chisquare for the relationship between the country of origin and 'strategic planning' was significant at the 0,012 level while that for 'long range planning' was significant at the 0,001 level. The disparity between the degrees of involvement in corporate planning by companies of different origins, is further highlighted in Table 2 . These finding are further reinforced by the overseas ownership figures shown in both Tables 1 and 2 . Although not tabulated in either Table 1 or 2 , the joint degrees of involvement in planning by companies of European origin, namely: France (4 responses), Germany (11 responses) and Italy ( 2 responses), were also examined. This small sample of onty 17 companies of European origin revealed lower percentages of involvement than South African companies in all areas of planning with the exception of the formulation of objectives, where 82,4 percent of these organizations undertook this activity compared with 79,7 percent for the South African companies. This result must, however, be viewed in the light of the small sample of European origin responses.

\section{Public/private sector involvement}

In the South African context the public sector incorporates all government and semi-government organizations such as the CSIR, SAR \& H, GPO, etc., public corporations such as ISCOR, SASOL and ESCOM as well as local authorities such as municipalities and town councils. The private sector embodies all private companies and those listed on the Johan- 
Table 1 Percentages of miscellaneous facets of organizations which undertake the various components of cor porate planning

\begin{tabular}{|c|c|c|c|c|c|c|c|}
\hline \multirow[b]{2}{*}{$\begin{array}{l}\text { Facets of organizations } \\
\text { (Row Percentages) }\end{array}$} & \multicolumn{7}{|c|}{ Components of corporate planning } \\
\hline & $\begin{array}{l}\text { Methods of } \\
\text { environmental } \\
\text { scanning }\end{array}$ & $\begin{array}{l}\text { Application } \\
\text { of } \\
\text { environmental } \\
\text { scanning }\end{array}$ & $\begin{array}{l}\text { Formulation } \\
\text { of objectives, } \\
\text { goals and } \\
\text { targets }\end{array}$ & $\begin{array}{l}\text { Strategic } \\
\text { planning }\end{array}$ & $\begin{array}{l}\text { Long range } \\
\text { planning }\end{array}$ & $\begin{array}{l}\text { Operational } \\
\text { planning }\end{array}$ & $\begin{array}{l}\text { No formal } \\
\text { corporate plans } \\
\text { derived }\end{array}$ \\
\hline \multicolumn{8}{|l|}{ Country of origin } \\
\hline South Africa & 74,0 & 72,4 & 79,7 & 69,5 & 64,4 & 89,2 & 6,7 \\
\hline Britain & 81,6 & 77,6 & 85,7 & 82,7 & 78,6 & 95,9 & 3,1 \\
\hline United States of America & 84,8 & 84,8 & 95,7 & 87,0 & 89.1 & 97,8 & 2,2 \\
\hline \multicolumn{8}{|l|}{$\begin{array}{l}\text { Public/Private sector } \\
\text { Government or Provincial }\end{array}$} \\
\hline Administration & 71,4 & 71,4 & 85,7 & 71,4 & 85,7 & 100,0 & 0,0 \\
\hline Semi-government & 80,0 & 80,0 & 80,0 & 80,0 & 60,0 & 80,0 & 20,0 \\
\hline Public Corporations & 83,3 & 83,3 & 100,0 & 83,3 & 83,3 & 100,0 & 0,0 \\
\hline Local Authorities & 50,0 & 50,0 & 75,0 & 50,0 & 75,0 & 75,0 & 25,0 \\
\hline Private Sector & 76,8 & 75,0 & 83,2 & 74,4 & 70,5 & 92,0 & 4,9 \\
\hline \multicolumn{5}{|l|}{ Ownership } & & & \\
\hline Institution(s) & 81,0 & 82,5 & 90,5 & $\begin{array}{l}74,0 \\
79,4\end{array}$ & 81,0 & $\begin{array}{l}83,0 \\
98,4\end{array}$ & $\begin{array}{l}9,6 \\
0.0\end{array}$ \\
\hline Local shareholders & 78,5 & 78,2 & 85,6 & 77,9 & 72,8 & 93,6 & 3.4 \\
\hline Overseas shareholders & 84,8 & 83,2 & 90,4 & 80,8 & 80,0 & 95,2 & 2,4 \\
\hline International parent company & 78,6 & 79,3 & 88,6 & 82.1 & 82,1 & 95,0 & 4,3 \\
\hline Municipal authority & 50,0 & 50,0 & 75,0 & 50,0 & 75,0 & 75,0 & 25,0 \\
\hline Government & 69,2 & 61,5 & 84,6 & 76,9 & 76,9 & 92,3 & 7,7 \\
\hline \multirow{2}{*}{\multicolumn{8}{|c|}{$\begin{array}{l}\text { Organizational form } \\
\text { Single independent organizational }\end{array}$}} \\
\hline & & & & & 44,8 & 76,1 & 16,4 \\
\hline Multiple interdependent organization & 81,1 & 77,2 & 82,7 & 75,6 & 74,0 & 96,1 & 2,4 \\
\hline Vertically integrated company & 88,9 & 83,3 & 94,4 & 86,1 & 83,3 & 97,2 & 0,0 \\
\hline Diversified major company & 77,1 & 75,9 & 84,3 & 78,3 & 77,1 & 92,8 & 4,8 \\
\hline Conglomerate company & 78,8 & 80,8 & 88,5 & 75,0 & 76,9 & 98,1 & 0,0 \\
\hline \multirow{2}{*}{\multicolumn{8}{|c|}{$\begin{array}{l}\text { Activity segments } \\
\text { Agriculture, hunting, forestry and }\end{array}$}} \\
\hline & & & & & 69,4 & 91.9 & 48 \\
\hline Mining and quarrying & 75,4 & 73,8 & 85,2 & $\begin{array}{l}0,0 \\
75,4\end{array}$ & $\begin{array}{l}0,4 \\
80,3\end{array}$ & 91,8 & $\begin{array}{l}4,8 \\
4,9\end{array}$ \\
\hline Manufacturing & 74,8 & 73,8 & 84,0 & 75,9 & 73,8 & 91,5 & 6,0 \\
\hline Electricity, gas and water & 77,8 & 77,8 & 94,4 & 83,3 & 83,3 & 94,4 & 0,0 \\
\hline Construction & 85,5 & 87,3 & 83,6 & 80,0 & 81,8 & 100,0 & 0,0 \\
\hline $\begin{array}{l}\text { Wholesale and retail trade and } \\
\text { catering and accommodation }\end{array}$ & & & & & & & \\
\hline & 76,4 & 73,2 & 82,9 & $\mathbf{7 4 , 8}$ & 69,1 & 91,9 & 4,1 \\
\hline $\begin{array}{l}\text { Transport, storage and postal } \\
\text { services }\end{array}$ & 77,3 & 79,5 & 86,4 & 77,3 & 77,3 & 90.9 & 6.8 \\
\hline $\begin{array}{l}\text { Financing, insurance, real estate } \\
\text { and business services }\end{array}$ & אוני & (2, & & (1,3) & $m, 3$ & 0,9 & 0,0 \\
\hline $\begin{array}{l}\text { and business services } \\
\text { Community, social and personal }\end{array}$ & 81,8 & 81,8 & 85,2 & 73,9 & 65,9 & 89,8 & 4,5 \\
\hline & 73,3 & 53,3 & 73,3 & 60,0 & 53,3 & 93.3 & 67 \\
\hline Organizational maturity & & & 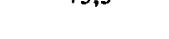 & $\infty, 0$ & 33,3 & $\mathbf{9 3 , 3}$ & 0,1 \\
\hline Infancy & 72,0 & 56,0 & 72,0 & 52,0 & 48,0 & 80,0 & 12,0 \\
\hline Growth & 80,9 & 80,0 & 80,9 & 76,5 & 70,4 & 93,0 & 5,2 \\
\hline Maturity & 72,4 & 70,3 & 83,2 & 73,1 & 71,0 & 91,3 & 5,9 \\
\hline Diversification & 84,3 & 88,0 & 86,7 & 80,7 & 74,7 & 94,0 & 2,4 \\
\hline Growth rate & & & & & & & \\
\hline Large contraction & 75,0 & 75,0 & 87,5 & 87,5 & 62,5 & 100,0 & 0,0 \\
\hline Contraction & 69,8 & 73,6 & 83,0 & 71,7 & 64,2 & 86,8 & 7.5 \\
\hline $\begin{array}{l}\text { Status quo } \\
\text { Expansion }\end{array}$ & 70,7 & 64,1 & 79,3 & 70,7 & 65,2 & 87,0 & 8.7 \\
\hline $\begin{array}{l}\text { Expansion } \\
\text { Large expansion }\end{array}$ & 78,1 & 76,3 & 82,0 & 74,2 & 71,4 & 92,6 & 4,9 \\
\hline Large expansion & 82,1 & 82,1 & 91,0 & 79,1 & 80,6 & 98,5 & 0,0 \\
\hline Profitability & & & & & & & \\
\hline Large loss & 88,9 & 88,9 & 77,8 & 55,6 & 55,6 & 100,0 & 0,0 \\
\hline Loss & 71,0 & 74,2 & 87,1 & 77,4 & 64,5 & 93,5 & 0,0 \\
\hline Break-even & 83,7 & 76,7 & 86,0 & 72,1 & 69,8 & 88,4 & 0,0 \\
\hline Profitable & 78,0 & 75,8 & 83,2 & 76,1 & 71,7 & 91,3 & 6,5 \\
\hline Very profitable & 74,2 & 73,1 & 82,8 & 73,1 & 72,0 & 95,7 & 3,2 \\
\hline Planning organization & & & & & & & \\
\hline Full-time formal corporate & & & & & & & \\
\hline $\begin{array}{l}\text { planning department at interna- } \\
\text { tional headquarters }\end{array}$ & 89,1 & 89,1 & 97,0 & 91,1 & 92,1 & 99,0 & 1,0 \\
\hline $\begin{array}{l}\text { Full-time formal corporate } \\
\text { planning department at local }\end{array}$ & & & & & & & \\
\hline headquarters & 90,4 & 92,2 & 95,7 & 90,4 & 91,3 & 100,0 & 0,0 \\
\hline $\begin{array}{l}\text { Full-time formal planning department } \\
\text { at subsidiary level }\end{array}$ & & & & & & & \\
\hline $\begin{array}{l}\text { a company } \\
\text { cory level or independent }\end{array}$ & 92,7 & 94,5 & 98,2 & 94,5 & 92,7 & 98,2 & 1,8 \\
\hline $\begin{array}{l}\text { Full-time formal planning department } \\
\text { at divisional level }\end{array}$ & 95,5 & 95,5 & 100,0 & 93,2 & 93,2 & 100,0 & 0,0 \\
\hline Planning activities done part- & & & & & & & \\
\hline $\begin{array}{l}\text { time as and when required by } \\
\text { operating company/division/ } \\
\text { department }\end{array}$ & 75,3 & 74,7 & 83,8 & 73,4 & 70,0 & 94,1 & 4,4 \\
\hline Planning approach & & & & & & & \\
\hline Bottom up & 81,8 & 75,0 & 81,8 & 75,0 & 75,0 & 93,2 & 6,8 \\
\hline Top-down & 79,6 & 80,4 & 85,2 & 77,8 & 73,0 & 96,1 & 2,6 \\
\hline Interactively & 76,6 & 77,2 & 90,3 & 80,7 & 80,0 & 95,9 & 3,4 \\
\hline $\begin{array}{l}\text { Plans prepared by corporate } \\
\text { planning department }\end{array}$ & 914 & 91,4 & 100,0 & 97,1 & 100,0 & 100,0 & 0,0 \\
\hline Planning expenditure & 91,4 & 31,4 & & & & & \\
\hline $0,0 \%$ to $0,9 \%$ & & 76,6 & 84,3 & 74,8 & 71.5 & 94,2 & 4,0 \\
\hline $1,0 \%$ to $2,9 \%$ & 85,7 & 84,8 & 93,3 & 88,6 & 87,6 & 99,0 & 0,0 \\
\hline $3,0 \%$ to $4,9 \%$ & 85,2 & 88,9 & 96,3 & 92,6 & 77,8 & 96,3 & 3,7 \\
\hline $5,0 \%$ to $6,9 \%$ & 66,7 & 77,8 & 88,9 & 77,8 & 66,7 & 88,9 & $\begin{aligned} 11,1 \\
0.0\end{aligned}$ \\
\hline $7,0 \%$ to $9,9 \%$ & 83,3 & 83,3 & 100,0 & 83,3 & 100,0 & 100,0 & 0,0 \\
\hline $10,0 \%$ and above & 72,7 & 81,8 & 90.9 & 72,7 & 63,6 & 100,0 & 0,0 \\
\hline
\end{tabular}


Table 2 Percentages of miscellaneous facets of organizations' degrees of involvement in the overall corporate planning process

\begin{tabular}{|c|c|c|c|c|}
\hline \multirow[b]{2}{*}{$\begin{array}{l}\text { Facets of organizations } \\
\text { (Row percentages) }\end{array}$} & \multicolumn{4}{|c|}{ Degrees of involvement in the overall corporate planning process } \\
\hline & $\begin{array}{c}\text { No } \\
\text { formal } \\
\text { involvement }\end{array}$ & $\begin{array}{c}\text { Low } \\
\text { formal } \\
\text { involvement }\end{array}$ & $\begin{array}{c}\text { Medium } \\
\text { formal } \\
\text { involvement }\end{array}$ & $\begin{array}{c}\text { High } \\
\text { formal } \\
\text { involvement }\end{array}$ \\
\hline \multicolumn{5}{|l|}{ Country of origin } \\
\hline South Africa & 5,1 & 18,7 & 28,9 & 47,3 \\
\hline Britain & 2,0 & 9,2 & 34,7 & 54,1 \\
\hline United States of America & 2,2 & 2,2 & 30,4 & 65,2 \\
\hline \multicolumn{5}{|l|}{ Public/Private sector } \\
\hline Government or Provincial Administration & 0,0 & 28,6 & 0,0 & 71,4 \\
\hline Semi-Government & 20,0 & 0,0 & 0,0 & 80,0 \\
\hline Public Corporation & 0,0 & 16,7 & 33,3 & 50,0 \\
\hline Local Authority & 0,0 & 50,0 & 25,0 & 25,0 \\
\hline Private Sector & 3,7 & 15,4 & 29,9 & 51,0 \\
\hline \multicolumn{5}{|l|}{ Ownership } \\
\hline Individual(s) & 7,2 & 24,0 & 27,2 & 41,6 \\
\hline Institution(s) & 0,0 & 12,7 & 27,0 & 60,3 \\
\hline Local shareholders & 2,3 & 13,4 & 31,9 & 52,3 \\
\hline Overseas shareholders & 1,6 & 11,2 & 24,0 & 63,2 \\
\hline International parent company & 2,9 & 9,3 & 30,7 & 57,1 \\
\hline Municipal authority & 0,0 & 50,0 & 25,0 & 25,0 \\
\hline Government & 7,7 & 15,4 & 23,1 & 53,8 \\
\hline \multicolumn{5}{|l|}{ Organizational forms } \\
\hline Single independent organizational unit & 14,9 & 28,4 & 25,4 & 31,3 \\
\hline Multiple interdependent organization & 1,6 & 15,0 & 31,5 & 52,0 \\
\hline Vertically integrated company & 0,0 & 5,6 & 27,8 & 66,7 \\
\hline Diversified major company & 3,6 & 9,6 & 38,6 & 48,2 \\
\hline Conglomerate company & 0,0 & 15,4 & 23,1 & 61,5 \\
\hline \multicolumn{5}{|l|}{ Activity segments } \\
\hline Agriculture, hunting, forestry and fishing & 4,8 & 8,1 & 33,9 & 53,2 \\
\hline Mining and quarrying & 1,6 & 14,8 & 24,6 & 59,0 \\
\hline Manufacturing & 4,6 & 13,8 & 26,2 & 55,3 \\
\hline Electricity, gas and water & 0,0 & 16,7 & 22,2 & 61,1 \\
\hline Construction & 0,0 & 10,9 & 23,6 & 65,5 \\
\hline \multicolumn{5}{|l|}{$\begin{array}{l}\text { Wholesale and retail trade and catering and } \\
\text { accommodation services }\end{array}$} \\
\hline $\begin{array}{l}\text { accommodation services } \\
\text { Transport, storage and postal services }\end{array}$ & 3,3 & 14,6 & 30,9 & 51,2 \\
\hline \multicolumn{5}{|l|}{$\begin{array}{l}\text { Financing, insurance, real estate and business } \\
\text { Fingerte }\end{array}$} \\
\hline services & 2,3 & 17,0 & 27,3 & 53,4 \\
\hline \multirow{2}{*}{\multicolumn{5}{|c|}{ Organizational maturity }} \\
\hline & & & & \\
\hline Infancy & 7,7 & 30,8 & 7,7 & 53,8 \\
\hline Growth & 5,2 & 14,3 & 33.8 & 46,8 \\
\hline Maturity & 5,7 & 14,2 & 32,7 & 47,4 \\
\hline Diversification & 1,9 & 14,4 & 26,0 & 57,7 \\
\hline \multicolumn{5}{|l|}{ Growth rate } \\
\hline Large contraction & 0,0 & 0,0 & 0,0 & 100,0 \\
\hline Contraction & 12,9 & 19,4 & 29,0 & 38,7 \\
\hline $\begin{array}{l}\text { Status quo } \\
\text { Expansion }\end{array}$ & 8,3 & 20,0 & 18,3 & 53,3 \\
\hline & 3,6 & 15,3 & 29,8 & 51,2 \\
\hline $\begin{array}{l}\text { Large expansion } \\
\text { Profitability }\end{array}$ & 0,0 & 4,3 & 44,7 & 51,1 \\
\hline $\begin{array}{l}\text { Profitability } \\
\text { Large loss }\end{array}$ & & & & \\
\hline $\begin{array}{ll}\text { Large loss } \\
\text { Loss }\end{array}$ & 0,0 & 50,0 & 0,0 & 50,0 \\
\hline Break-even & 0,0 & 18,8 & 43,8 & 37,5 \\
\hline Profitable & 0,0 & 15,8 & 26,3 & 57,9 \\
\hline Very profitable & 4,9 & 13,2 & 30,2 & 51,7 \\
\hline Planning organization & 4,8 & 15,9 & 28,6 & 50,8 \\
\hline $\begin{array}{l}\text { Full-time formal corporate planning department } \\
\text { at international headourters }\end{array}$ & & & & \\
\hline & 1,0 & 3,0 & 18,8 & 77,2 \\
\hline $\begin{array}{l}\text { at local headquarters } \\
\text { Full-time formal planning department at subsidiary }\end{array}$ & 0,0 & 3,5 & 20,0 & 76,5 \\
\hline level or independent company & 1,8 & 0,0 & 12,7 & 85,5 \\
\hline $\begin{array}{l}\text { Full-time formal planning department at } \\
\text { divisional level }\end{array}$ & & & & \\
\hline $\begin{array}{l}\text { Planning activities done part-time as and when } \\
\text { required by operating company/division/ }\end{array}$ & 0,0 & 2,3 & 13,6 & 84,1 \\
\hline department & 2,2 & 15,6 & 34,4 & 47,8 \\
\hline $\begin{array}{l}\text { Planning approach } \\
\text { Bottom-up }\end{array}$ & & & & \\
\hline Top-down & 6,8 & 9,1 & 36,4 & 47,7 \\
\hline Interactively & 0,9 & 12,2 & 30,4 & 56,5 \\
\hline Plans prepared by corporate planning department & 1,4 & 13,1 & 32,4 & 53,1 \\
\hline $\begin{array}{l}\text { Planning expenditure } \\
0.0 \% \text { to } 0.9 \%\end{array}$ & 0,0 & 2,9 & 14,3 & 82,9 \\
\hline $\begin{array}{l}0,0 \% \text { to } 0,9 \% \\
1,0 \% \text { to } 2,9 \%\end{array}$ & 2,6 & 13,9 & 32,1 & 51,5 \\
\hline $3,0 \%$ to $4,9 \%$ & 0,0 & 7,6 & 28,6 & 63,8 \\
\hline $5,0 \%$ to $6,9 \%$ & 0,0 & 7,4 & 14,8 & 77,8 \\
\hline $7,0 \%$ to $9,9 \%$ & 11,1 & 11,1 & 11,1 & 66,7 \\
\hline $10,0 \%$ and above & 0,0 & 16,7 & 0,0 & 83,3 \\
\hline & 0,0 & 9,1 & 45,5 & 45,5 \\
\hline
\end{tabular}


nesburg Stock Exchange. An interesting and unexpected observation can be seen in the tabulation of organizations from the public and private sectors, although the relationship is not statistically significant. These tabulations show that the public sector is highly involved in all aspects of planning. The only exception to this appears to be local authorities such as Municipalities and Town Councils. This exception may well be accounted for by their strong service rather than profit motive. In the case of the other public sectors, their high degree of involvement in planning may well be the integrative role played by planning rather than the profit motive. In addition, large government bodies require detailed budgets and in certain cases are accountable to parliament for budget approval and long term capital expenditure. Many of the large government departments such as defence, transport and postal/telecommunications services are very capital intensive. The long lead times involved in new projects often require the application of sophisticated managerial approaches to ensure the best use of the taxpayers money, which could well explain their high levels of involvement in corporate planning.

\section{Structural forms of organizations}

Table 2 shows the apparent higher need for planning by vertically integrated and conglomerate companies where the integrative role of planning would seem to dominate. It should be noted, however, that the chi-square for the relationships between overall planning involvement and both vertically integrated and conglomerate organizations indicated that neither was statistically significant. A point of particular interest in this regard is the declining involvement in strategic planning as organizations increase their level of diversification. Table 1 shows that $86,1 \%$ of the vertically integrated companies undertook strategic planning which decreased to $78,3 \%$ for diversified major companies and finally down to $75,0 \%$ for conglomerate companies. In this regard, the chi-square for the relationship between involvement in 'Strategic planning' and 'Vertically integrated' companies was significant at the 0,015 level, but that the relationships with 'Diversified major' and 'Conglomerate' companies were statistically independent. Although only one of the above three relationships were significant, these results are in line with the findings of Lorsch and Allen (1973), who found that vertically integrated companies were likely to require more complex integrative devices than conglomerates.

\section{Activity segment involvement}

Both Tables 1 and 2 show that the construction industry was involved to a high degree in planning, although the chi-square indicated that this relationship was statistically independent $(0,088)$. This apparent dominance could well be attributed to planning's role in coping with the very uncertain environment in which the depressed construction industry in South Africa was operating unlike planning's integrative organizational role in other sectors. Again, like the public sector discussed earlier, the construction industry also requires planning to cope with a capital intensive industry and long lead times.

\section{Organizational age, maturity and growth}

The tabulation of organizational maturity in Table 1 reveals several interesting aspects of planning. Firstly, companies in their infancy, appear to become highly involved in planning so as to cope with the high uncertainty of the new venture. During their growth and maturity stages, their planning involvement appears to shift to between a medium and high level of involvement. Finally, as the organizations enter into a diversification phase, the emphasis on planning appears to shift back to a high level of involvement. These conclusions are suggested by the survey data, but the chi-square indicated that the relationship was not statistically significant.

The above findings do not at first glance appear reconcilable with those discussed earlier. It will be recalled that as organizations increased in age, size and complexity, their degrees of involvement in corporate planning increased along the continuum. In reconciling these two apparently contradictory findings, it is necessary to bear in mind that physical age and organizational maturity are two totally different concepts. On the one hand, physical age is time dependent, whereas maturity is industry/product/market 'life cycle' dependent. Time horizons or life cycles can be as short as several months for highly innovative product industries, or as long as fifty or more years for the forestry and mining industries. These examples clearly illustrate that it is virtually impossible to relate physical age to life cycle maturity and thus the findings above are not necessarily contradictory.

The above observations on maturity appear to be borne out by the tabulations of growth rates in Table 2 . It can immediately be seen from this table, that a high level of involvement in planning is required at both ends of the growth continuum where strong integrative needs are evident. The chi-square for this relationship is statistically significant at the 0,014 level. Under the duress of extreme contraction and loss of market share, a high involvement in planning $(100,0 \%)$ by all organizations operating under these conditions appears to be resorted to in an effort to 'pull the chestnuts out of the fire'. At the other end of the continuum, where a large expansion is taking place, it can be seen from the tabulation that $95,8 \%$ percent of organizations operating under these conditions were either medium involved $(44,7 \%)$ or highly involved $(51,1 \%)$ in corporate planning. The growth rates in Table 1 also show that the 'status quo' companies are relatively less involved than the 'contraction' or 'expansion' companies in so far as application of scanning, formulation of objectives and strategic planning are concerned, although none of these relationships are statistically significant. Involvement in these components of planning are seen to increase progressively as the degree of expansion or contraction increases. It is particularly interesting to note the 'strategic planning' dichotomy between contracting and expanding companies while a steadily increasing continuum is seen for the 'long range planning' component. This latter observation clearly highlights the shorter term strategic emphasis required to cope with immediate needs as opposed to the longer term future needs of the company. In this regard, the chi-square indicated statistical independence for the strategic planning relationship, but statistical significance at the 0,026 level for the long range planning relationship.

\section{Profitability and planning involvement}

Several interesting relationships between profitability and the various components of corporate planning are suggested by the survey data. The 'large loss' companies appeared to be more heavily involved in looking at the environment and deriving short term operational plans than the other more profitable companies. These 'large loss' companies also had a lower involvement in the 'formulation of objectives' and the lowest involvement in both 'strategic' and 'long range planning'. Involvement in long range planning by all companies showed a clear increasing continuum as these companies became progressively more profitable. This continuum showed that only 
$55,6 \%$ of the 'large loss' companies undertook 'long range planning' as opposed to $72,0 \%$ of the 'very profitable' companies. Although the above interesting observations were suggested by the data, none of the relationships were statistically significant.

\section{Administrative facets of planning}

To fully examine the administrative facets of planning, tabulations were also constructed to show the relationships between these facets and the four organizational clusters as well as the two and four environmental clusters. The results of these tabulations are reproduced in Tables 3 and 4 . It should be noted that column percentages are presented in these tables. Further, because the 'planning organization' tabulation was derived from a multiple response question, the percentages do not add up to 100,0 .

\section{Planning organization}

As could be expected, a higher level of involvement in planning was found in cases where a formal planning department was in operation. Table 2 clearly shows that between 76 and $85 \%$ of the companies with formal planning departments were highly involved in the process, whereas only $47 \%$ of companies undertaking part-time planning were highly involved. The chisquare for the formal planning department relationship was statistically significant at the 0,0001 level while that for parttime planning was significant at the 0,0009 level. The influence of a corporate planning department can also be seen in the tabulation of planning approach in Table 2, where $82,9 \%$ of the companies in which plans were prepared by a corporate planning department were highly involved in the process. The chi-square of this latter relationship is statistically significant at the 0,0127 level.

Table 3 clearly shows that as the organizational continuum grows from the smaller to the larger organizations, so also does the percentage of organizations with the various levels of planning departments grow. The strong integrative needs of the administratively centralized Cluster 1 are again seen in its dominance of full-time planning departments at both International Headquarters and subsidiary levels. Part-time planning predominates in the smaller organizations and is further seen to steadily decline as the organizations increase in size and complexity along the continuum. The chi-square for all of the full-time planning department relationships with the organizational clusters were statistically significant at the 0,004 level or better but the part-time relationship with the organizational clusters was found to be statistically independent.

Table 4 shows the planning organizations related to the two and four cluster environments. The two cluster solution appears to suggest that a greater percentage of organizations have one or more of the various full-time planning departments when operating in the dynamic/heterogeneous environment than those operating under stable/homogeneous conditions. Conversely, part-time planning appears to be used by a higher percentage of organizations operating under stable/homogeneous than those operating under dynamic/heterogeneous conditions. In other words, the greater the environmental uncertainty, the greater the need for formalized planning. Although the above environmental relationships are suggested by the data, the chi-square for each type of planning organization is not statistically significant.

Table 3 Percentages of the various administrative facets of planning for four cluster organizations

\begin{tabular}{|c|c|c|c|c|}
\hline & \multicolumn{4}{|c|}{ Four organizational clusters } \\
\hline & \multicolumn{2}{|c|}{ Organic traits } & \multicolumn{2}{|c|}{ Mechanistic traits } \\
\hline & Cluster 2 & Cluster 4 & Cluster 1 & Cluster 3 \\
\hline $\begin{array}{l}\text { Administrative facets of planning } \\
\text { (Column percentages) }\end{array}$ & $\begin{array}{l}\text { Small decentralized } \\
\text { organic organi- } \\
\text { zations }\end{array}$ & $\begin{array}{l}\text { Large centralized } \\
\text { semi-organic organi- } \\
\text { zations }\end{array}$ & $\begin{array}{l}\text { Centralized mecha- } \\
\text { nistic organizations }\end{array}$ & $\begin{array}{l}\text { Deceniralized mecha- } \\
\text { nistic/bureaucratic } \\
\text { organizations }\end{array}$ \\
\hline \multicolumn{5}{|l|}{$\begin{array}{l}\text { Planning organizations } \\
\text { Full-time corporate planning denartment }\end{array}$} \\
\hline $\begin{array}{l}\text { international headquarters } \\
\text { Full-time formal corporate planning department }\end{array}$ & 6,5 & 21,4 & 31,3 & 28,3 \\
\hline $\begin{array}{l}\text { at local headquarters } \\
\text { Full-time formal planning department at subsidiary }\end{array}$ & 6,5 & 14,3 & 25,8 & 40,1 \\
\hline $\begin{array}{l}\text { level or independent company } \\
\text { Full-time formal planning department at }\end{array}$ & 2,2 & 5,4 & 18,0 & 16,4 \\
\hline $\begin{array}{l}\text { divisional level } \\
\text { Planning activities done part-time as and when }\end{array}$ & 0,0 & 3,6 & 7,0 & 19,7 \\
\hline required by operating company/division/department & 93,5 & 76,8 & 67,2 & 61,8 \\
\hline \multicolumn{5}{|l|}{ Planning approach } \\
\hline Top-down & 15,2 & 5,4 & 8,3 & 11,1 \\
\hline Interactively & 60,9 & 53,6 & 42,9 & 52,9 \\
\hline Plans prepared by corporate planning department & 23,9 & 33,9 & 38,3 & 27,5 \\
\hline \multicolumn{5}{|l|}{$\begin{array}{l}\text { Planning expenditure } \\
\text { (a) By category }\end{array}$} \\
\hline $\begin{array}{l}0 \% \text { to } 0,9 \% \\
1 \% \text { to } 2,9 \%\end{array}$ & 82,7 & 54,5 & 64,3 & 62,7 \\
\hline $3 \%$ to $4,9 \%$ & 12,8 & 32,7 & 25,4 & 24,6 \\
\hline $5 \%$ to $6,9 \%$ & 0,0 & 7,3 & 7,1 & 4.9 \\
\hline $7 \%$ to $9,9 \%$ & 0,0 & 0,0 & 0,8 & 2,8 \\
\hline $10 \%$ and above & 0,0 & 3,6 & 0,0 & 1,4 \\
\hline \multirow{2}{*}{\multicolumn{5}{|c|}{$\begin{array}{l}\text { (b) Cumulative } \\
\text { Less than } 1 \%\end{array}$}} \\
\hline & & & & \\
\hline $\begin{array}{l}\text { Less than } 3 \% \\
\text { Less than } 5 \%\end{array}$ & 100,0 & $\begin{array}{l}34,5 \\
87,2\end{array}$ & $\begin{array}{l}64,3 \\
89,7\end{array}$ & $\begin{array}{l}62,7 \\
87,3\end{array}$ \\
\hline Less than $7 \%$ & 100,0 & 94,5 & 96,8 & 92,2 \\
\hline Less than $10 \%$ & 100,0 & 94,5 & 97,6 & 95,0 \\
\hline \multirow{2}{*}{$10 \%$ and above } & 100,0 & 98,1 & 97.6 & 96.4 \\
\hline & 0,0 & 1,9 & 2,4 & 3,6 \\
\hline
\end{tabular}




\section{Planning approach}

The 'top-down' approach to planning is seen from Table 3 to be the dominant approach for all of the organizational forms, followed by the 'interactive' approach. In relation to each of the other clusters, it is seen that a greater percentage of the smaller decentralized organizations use the 'top-down' and 'bottom-up' approaches whereas the greatest percentage of 'interactive' and 'planning' department preparations are found in the centralized Cluster 1 organizations. It can be further seen that the two decentralized clusters at each end of the continuum have a lower percentage of 'interactive' companies whereas the two centralized clusters in the middle of the continuum have higher percentages of 'interactive' companies. Conversely, the two decentralized clusters have higher percentages of 'bottom-up' companies, while the two centralized clusters have lower percentages of 'bottom-up' companies. Although these results appear at first to be a contradiction of the cluster characteristics, the interactive planning process may well be an important means of overcoming some of the limitations of strongly centralized organizations. Another possible reason for this apparent contradiction is that disciplined formal planning could only function in an informal organization if forced on the organization by a strong 'top-down' dictatorial approach. Although relationships were suggested by the data, the chi-square for these relationships were statistically independent $(0,1077)$.

The 'top-down' approach to planning is again seen to dominate under all environmental conditions, followed by the 'interactive' approach as shown in Table 4. It can also be seen that as the environment becomes more complex, the 'top- down' approach decreases and the 'interactive' process increases. It is interesting to note that a greater percentage of plans prepared by corporate planning departments are for those organizations operating in the more certain environments. This could be explained by the presence of a formal planning department enabling an organization to perceive its environment as being more certain because of its greater knowledge of the environment. Although the above relationships were again suggested by the data, the chi-square for these relationships were statistically independent.

\section{Planning expenditure}

Planning expenditure is presented by both category and cumulative tabulations. The category tabulation reveals that more than half of all companies spend less than $1 \%$ and more than $87 \%$ spend less than $3 \%$ of their total sales value on the important management function of corporate planning. The cumulative tabulation clearly shows that for less than $10 \%$ of expenditure on planning, a steady decline occurs from the young small organizational end of the continuum to the older larger end. Conversely, for expenditures greater than 10\%, a steady increase is observed along the continuum. This clearly shows that the smaller companies spend less on planning and as the companies get larger and more complex they tend to spend relatively more on planning, particularly the large public sector type organizations. Although suggested by the data, the chi-square for this relationship was statistically independent.

The influence of environmental uncertainty on planning expenditure is best shown in the two cluster cumulative tabulation. This tabulation clearly shows that more is spent on plan-

Table 4 Percentages of the various administrative facets of planning for two and four cluster environments

\begin{tabular}{|c|c|c|c|c|c|c|}
\hline \multirow[b]{3}{*}{$\begin{array}{l}\text { Administrative facets of planning } \\
\text { (Column percentages) }\end{array}$} & \multicolumn{2}{|c|}{ Two cluster environments } & \multicolumn{4}{|c|}{ Four cluster environments } \\
\hline & Cluster 1 & Cluster 2 & Cluster 2 & Cluster 1 & Cluster 3 & Cluster 4 \\
\hline & $\begin{array}{l}\text { Stable, homo- } \\
\text { geneous environ- } \\
\text { ment }\end{array}$ & $\begin{array}{l}\text { Dynamic, } \\
\text { heterogeneous } \\
\text { environment }\end{array}$ & $\begin{array}{l}\text { Stable, homo- } \\
\text { geneous environ- } \\
\text { ment }\end{array}$ & $\begin{array}{c}\text { Dynamic, } \\
\text { homogeneous } \\
\text { environment }\end{array}$ & $\begin{array}{l}\text { Stable, hetero- } \\
\text { geneous environ- } \\
\text { ment }\end{array}$ & $\begin{array}{l}\text { Dynamic, } \\
\text { heterogeneous } \\
\text { environment }\end{array}$ \\
\hline Planning organization & & & & & & \\
\hline $\begin{array}{l}\text { Full-time formal corporate planning depart- } \\
\text { ment at international headquarters }\end{array}$ & 18,8 & 26,7 & 33.3 & 17,7 & 27,7 & 25,3 \\
\hline $\begin{array}{l}\text { Full-time formal corporate planning depart- } \\
\text { ment at local headquarters }\end{array}$ & 19,8 & 27,9 & 20,0 & 20,8 & 25,3 & 30.4 \\
\hline $\begin{array}{l}\text { Full-time formal planning depart- } \\
\text { ment at subsidiary level or indepen- } \\
\text { dent company }\end{array}$ & 6,9 & 13,4 & 6,7 & 8.3 & 13,3 & 12.7 \\
\hline $\begin{array}{l}\text { Full-time formal planning depart- } \\
\text { ment at divisional level }\end{array}$ & 8,9 & 12,8 & 13,3 & 8,3 & 13,3 & 12,7 \\
\hline $\begin{array}{l}\text { Planning activities done part-time as } \\
\text { and when required by operating company/ } \\
\text { division/department } \\
\text { Planning approgch }\end{array}$ & 78,2 & 68,6 & 73,3 & 77,1 & 71,1 & 67,1 \\
\hline $\begin{array}{l}\text { Planning approach } \\
\text { Bottom-up } \\
\text { Top-down } \\
\text { Interactively }\end{array}$ & $\begin{array}{r}9,3 \\
54,6 \\
27,8\end{array}$ & $\begin{array}{r}9.1 \\
53,1 \\
32,0\end{array}$ & $\begin{array}{r}7,1 \\
57,1 \\
28,6\end{array}$ & $\begin{array}{r}8,4 \\
55,8 \\
27,4\end{array}$ & $\begin{array}{l}10,8 \\
48,2 \\
36,1\end{array}$ & $\begin{array}{r}8,8 \\
56,3 \\
28,8\end{array}$ \\
\hline $\begin{array}{l}\text { Plans prepared by corporate planning } \\
\text { department }\end{array}$ & 8,2 & 5,7 & 7,1 & 8.4 & 4,8 & 6,3 \\
\hline $\begin{array}{l}\text { Planning expenditure } \\
\text { (a) By category } \\
0 \% \text { to } 0,9 \% \\
1,0 \% \text { to } 2,9 \% \\
3,0 \% \text { to } 4,9 \% \\
5,0 \% \text { to } 6,9 \% \\
7,0 \% \text { to } 9,9 \% \\
10,0 \% \text { and above } \\
\text { (b) Cumulative }\end{array}$ & $\begin{array}{r}73,2 \\
18,6 \\
4,1 \\
1,0 \\
1,0 \\
2,1\end{array}$ & $\begin{array}{r}55,3 \\
25,9 \\
9,4 \\
4,1 \\
1,2 \\
4,1\end{array}$ & $\begin{array}{r}80,0 \\
20,0 \\
0,0 \\
0,0 \\
0,0 \\
0,0\end{array}$ & $\begin{array}{r}70,7 \\
18,5 \\
6,5 \\
1,1 \\
1,1 \\
2,2\end{array}$ & $\begin{array}{r}53,1 \\
30,9 \\
7,4 \\
6,2 \\
1,2 \\
1,2\end{array}$ & $\begin{array}{r}57,0 \\
21,5 \\
10,1 \\
2,5 \\
1,3 \\
7,6\end{array}$ \\
\hline $\begin{array}{l}\text { (b) Cumulative } \\
\text { Less than } 1 \% \\
\text { Less than } 3 \% \\
\text { Less than } 5 \% \\
\text { Less than } 7 \% \\
\text { Less than } 10 \%\end{array}$ & $\begin{array}{l}73,2 \\
91,8 \\
95,9 \\
96,9 \\
97,9\end{array}$ & $\begin{array}{l}55,3 \\
81,2 \\
90,6 \\
94,7 \\
95,9\end{array}$ & $\begin{array}{r}80,0 \\
100,0 \\
100,0 \\
100,0 \\
100,0\end{array}$ & $\begin{array}{l}70,7 \\
89,2 \\
95,7 \\
96,8 \\
97,9\end{array}$ & $\begin{array}{l}53,1 \\
84,0 \\
91,4 \\
97,6 \\
98,8\end{array}$ & $\begin{array}{l}57,0 \\
78,5 \\
88,6 \\
91,1 \\
92,4\end{array}$ \\
\hline $10 \%$ and above & 2,1 & 4,1 & 0,0 & 2,1 & 1,2 & 7,6 \\
\hline
\end{tabular}


ning activities by organizations operating in the uncertain dynamic/heterogeneous environment than those operating in the more certain stable/homogeneous environment, although the chi-square of this relationship was statistically independent. The above relationship can be expected since it was shown earlier that organizations increased their involvement in planning as the operational environment became more complex and uncertain.

\section{Managerial involvement and the Influence of planning departments}

A determination of managements' degree of involvement in the planning process was ascertained by obtaining mean values for each activity undertaken at each hierarchical level. Mean scores were first determined for each activity and level for the total organizational sample and then for each of five organizational clusters. Five clusters were chosen so as to highlight any peculiarities which may exist in the higher order solutions. Oneway analyses of variance between the scores of involvement in planning at the various managerial levels and organizational clusters indicated $F$ probabilities of less than 0,0001 for each of the managerial levels with the exception of the Board of Directors where the $F$ probability was 0,0264 . The results of this analysis are shown in Table 5. The first part of this Table clearly shows that the chief executive plays an overall dominant role as well as a dominant role for all specific ac- tivities with the exception of methods of scanning and operational planning, where the operating managers have a greater degree of involvement. To test whether or not the difference between the means of the chief executive's scores and those of the operating managers' were significant, the Student's $t$ and probability levels were computed. The results of this computation indicated that the difference between the mean score of the chief executive for 'methods of scanning' and that of the operating managers was not significant, but that the differences between means for 'application of scanning', 'formulation of objectives', 'strategic planning', 'long range planning', 'operational planning' and 'overall involvement' were all significant. Relationships which are similar to those discussed above are also seen in the balance of the table for each of the five clusters.

It is interesting to note, however, that the differential between the chief executive's involvement and that of the operating managers, decrease as the size and complexity of the organizational clusters increase. In fact, the decentralized cluster at the end of the continuum shows that the chief executive and operating manager's participation overall are the same. The two smaller organizational clusters show a very low level of involvement by planning departments, whereas the three larger clusters show roughly the same level of participation which is somewhat lower than that of either the chief executive or operating manager's. Overall and for each cluster, the board

Table 5 Degrees of involvement in planning at different managerial levels for the total organizational sam. ple and five cluster categorizations

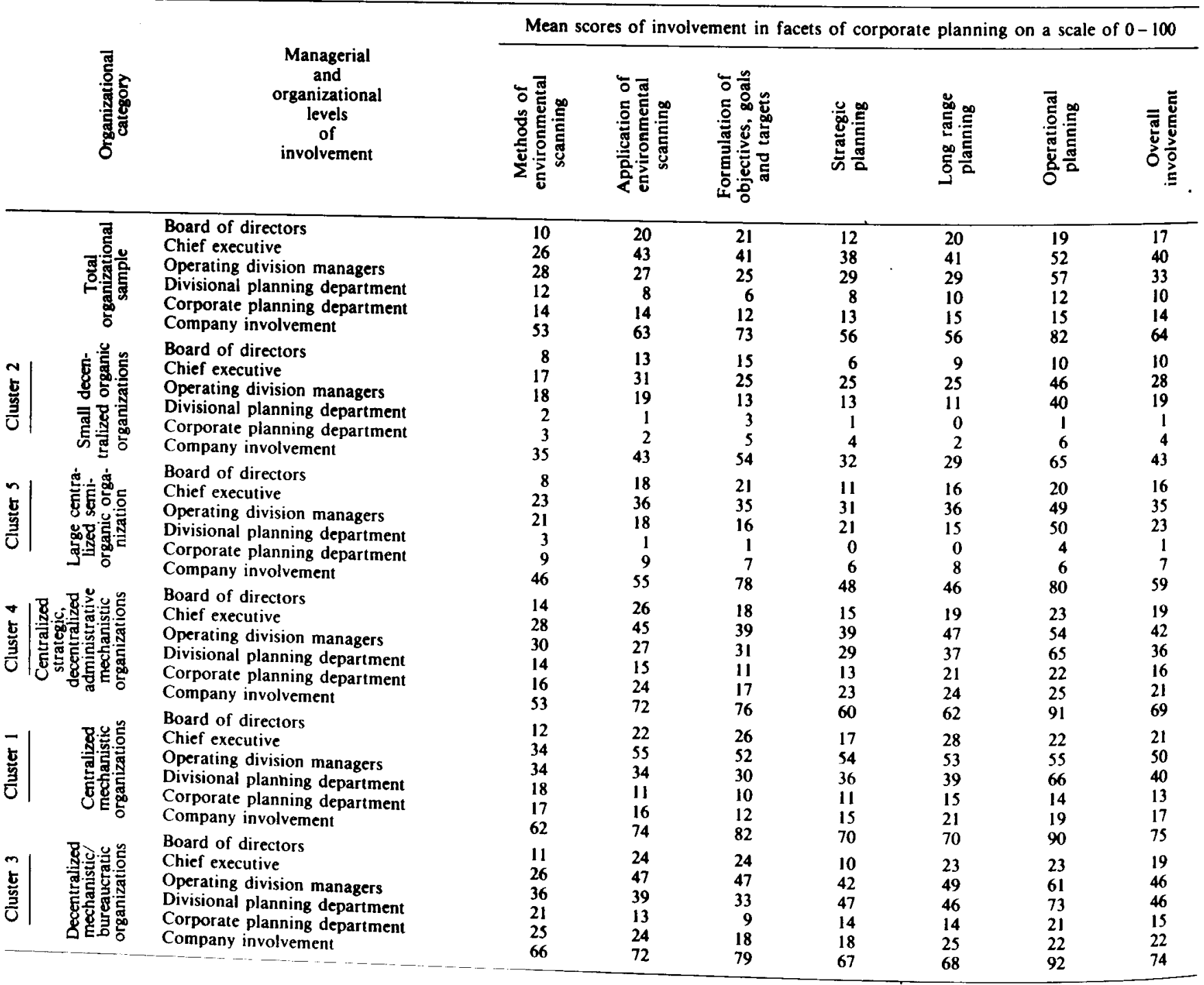


of directors play a very minor part, with the formulation of objectives receiving their highest degree of involvement. The overall company involvement in each activity is again seen to progressively increase as the organizational clusters increase in size and complexity along the continuums discussed earlier.

The data discussed above and presented in Table 5 was then split up into similar tables for each of the five planning organizations in operation, that is, for those organizations in which their international headquarters had full-time formal corporate planning departments through to those organizations in which only part-time planning was undertaken. One-way analyses of variance were used to analyse the five separate sets of data as well as the five organizational clusters within each of the five data sets. These analyses indicated statistically significant $F$ probabilities for those groups of organizations which had a full-time planning department at international headquarters and for those organizations in which part-time planning was undertaken. The $F$ probabilities were not significant, however, for those groups of cases in which use was made of a full-time planning department at either local headquarters, subsidiary or divisional level. From these analyses it was inferred that reliance should not be placed on the observations across the individual organizational clusters in which the various planning departments were in use. It is interesting to note that irrespective of the presence of one or more formal planning departments, the chief executive and operating managers still play a dominant role in the planning process. $\mathbf{A}$ further interesting aspect is that the differential gap between the chief executive and operating managers decrease as formal planning departments extend into the lower levels of the organization. In fact, when formal planning departments are at divisional level, it appears from the data that the divisional manager's involvement in planning exceeds that of the chief executive. To test whether or not the difference between the means of the chief executive's scores and those of the operating managers were significant for those groups of organizations in which the different forms of planning departments were in use, the Student's $t$ and probability levels were computed for each group. The results of this computation indicated that the difference between the mean score of the chief executive and that of the operating managers was significant for those cases in which a full-time planning department was in operation at international headquarters and for those cases in which parttime planning was undertaken. The difference between the means were not significant, however, for those cases in which full-time planning was undertaken at either local headquarters, subsidiary or divisional level. These results are in line with those found earlier in the one-way analyses of variance for the groups across the five organizational clusters.

Although the above finding is not statistically significant it is nevertheless highly predicted and in line with that of Lorsch and Allen (1973). They found that if divisions were to be effective in dealing with their individual portions of the total environment they would need to develop internal organizational practices which were consistent with the nature of the environment. This consistency between divisional organization and environment was important in that it enabled the divisional managers to effectively process information from the environment and reach decisions. This interface between divisional organizations and the environment led to differentiation between divisional managers and corporate managers since corporate managers dealt with that part of the total corporate environment which was different from that of any division. This differentiation between corporate and divisıonal managers was necessary for each to perform their own tasks effectively, but also contributed to the problems of achieving corporatedivisional integration. Effective decision making was further found by Lorsch and Allen (1973) to be facilitated by an exchange of information and resolution of conflict across the corporate-divisional interface. In some cases they found a balance of influence between corporate and divisional units while in others the division actually had greater influence than the headquarters. Lorsch and Allen (1973) concluded that this influence distribution suggested the level of balance that had been achieved in the decision-making process between corporate control and divisional autonomy in those organizations.

Although not statistically significant, the overall company involvement was also seen to increase as the planning departments extend to the lower levels of the organization. It is further interesting to note that corporate and divisional planning departments only start to play a role in the larger organizations, with virtually no involvement in the smaller organizations. The effects of part-time planning on the degrees of involvement, stand out in stark contrast with the full-time effects.

Considerably lower degrees of involvement in the various facets of corporate planning at each managerial level was seen in the total organizational sample when planning was undertaken part-time. Similarly, lower involvement was also found across each of the five organizational clusters.

\section{Interest group influence on the formulation of objectives}

This analysis was undertaken in an effort to determine the influence wielded by various internal and external groups on the formulation of the three basic types of objectives. Data for this analysis were captured in the questionnaire where separate tables were used to measure the individual group influences on four-point scales, ranging from 'Little or None' through to 'A very great extent', for each of the three classes of objectives. Each of these tables were then factor analysed separately. The results of these analyses indicated the need to delete the last item in each table, namely: the 'Others' category, as most of the respondents had not completed this item in any of the three tables. The tables were then re-factor analysed with the last item in each omitted.

\section{Participant objectives}

The first tabulation generated by the analysis of 'Participant Objectives' showed the means and standard deviations of the interest group influences on this class of objective. The individual interest groups, in decreasing order of mean influence were:

(i) chief executive $(3,73)$,

(ii) directors $(3,04)$,

(iii) divisional management $(3,02)$,

(iv) competitors $(2,71)$,

(v) customers $(2,68)$,

(vi) departmental management $(2,48)$,

(vii) government legislators $(2,34)$,

(viii) shareholders $(2,01)$,

(ix) employees $(1,81)$,

(x) creditors $(1,55)$.

The factor analysis produced three factors with Eigenvalues greater than 1,0 . The rotated factor matrix revealed the following group loadings on the three factors:

Factor 1: Chief Executive (0,32), Divisional Management $(0,77)$,

Departmental Management $(0,93)$ and 
Employees $(0,52)(53,0 \%$ of variance);

Factor 2: All External Groups

(29,8\% of variance);

Factor 3: Shareholders $(0,38)$ and Directors $(0,95)$

( $17,1 \%$ of variance).

This factor analysis showed that the ten individual interest group influences on the formulation of participant objectives could be roughly reduced to three combined interest groups. The overall mean influence of each of these three groups indicated very roughly that the strongest influence $(2,76$ on the four-point scale) comes from the group comprising factor 1 loadings, that is, the Chief Executive, Divisional and Departmental Managements and the Employees. This is followed by the influence (2,53 on the four-point scale) of the group comprising factor 3 loadings, that is, the Shareholders and Directors. The third influence (2,32 on the four-point scale) comes from the group comprising factor 2 loadings, that is, the external groups comprising Government Legislators, Customers, Creditors and Competitors.

\section{Strategic objectives}

The first tabulation generated by the analysis of 'Strategic Objectives' showed the means and standard deviations of the interest group influence on this class of objective. The individual interest groups, in decreasing order of mean influence were:

(i) chief executive $(3,66)$,

(ii) divisional management $(3,23)$,

(iii) customers $(3,11)$,

(iv) competitors $(2,98)$,

(v) directors $(2,80)$,

(vi) departmental management $(2,53)$,

(vii) government legislators $(2,05)$,

(viii) shareholders $(1,63)$,

(ix) employees $(1,55)$,

(x) creditors $(1,40)$.

The factor analysis produced three factors with Eigenvalues greater than 1,0 . The rotated factor matrix revealed the following group loadings on the three factors:

Factor 1: Divisional Management $(0,49)$,

Departmental Management $(0,89)$, and

Employees $(0,59)$,

$(54,2 \%$ of variance);

Factor 2: Customers $(0,69)$,

Creditors $(0,30)$, and

Competitors $(0,73)$,

(26,6\% of variance);

Factor 3: Shareholders $(0,41)$,

Directors $(0,81)$, and

Chief executive $(0,27)$

$(19,2 \%$ of variance).

The above factor analysis showed that the ten individual interest group influences on the formulation of strategic objectives could be roughly reduced to three combined interest groups. The overall mean influence of each of these three groups indicated very roughly that the strongest influence $(2,70$ on the four-point scale) comes from the group comprising factor 3 loadings, that is, the Shareholders, Directors and Chief Executive. This is followed by the influence $(2,50$ on the fourpoint scale) of the group comprising factor 2 loadings, that is Customers, Creditors and Competitors. The third influence $(2,44$ on the four-point scale) comes from the group comprising factor 1 loadings, that is Division Management, Departmental Management and Employees.

\section{Performance objectives}

The first tabulation generated by the analysis of 'Performance Objectives' showed the means and standard deviations of the interest group influences on this class of objective. The individual interest groups, in decreasing order of mean influence were:

(i) chief executive $(3,79)$,

(ii) directors $(3,26)$,

(iii) divisional management $(3,06)$,

(iv) competitors $(2,40)$,

(v) departmental management $(2,39)$,

(vi) shareholders $(2,38)$,

(vii) customers $(2,31)$,

(viii) government legislators $(2,07)$,

(ix) creditors $(1,59)$,

(x) employees $(1,58)$.

The factor analysis produced three factors with Eigenvalues greater than 1,0 . The rotated factor matrix revealed the following group loadings on the three factors:

Factor 1: Divisional Management $(0,70)$, Departmental Management $(0,92)$ and employees $(0,54)$ $(50,2 \%$ of variance);

Factor 2: All External Groups (28,7\% of variance); Factor 3: Directors $(0,98)$, Shareholders $(0,36)$ and Chief Executive $(0,31)(21,0 \%$ of variance).

The above factor analysis showed that the individual interest group influence on the formulation of performance objectives could be reduced to three combined interest groups. The overall mean influence of each of these three groups indicated very roughly that the strongest influence $(3,14$ on the four-point scale) comes from the group comprising factor 3 loadings, that is, Shareholders, Directors and Chief Executive. This is followed by the influence (2,34 on the four-point scale) of the group comprising factor 1 loadings, that is, Departmental Management, Divisional Management and Employees. This third influence (2,09 on the four-point scale) comes from the group comprising Government Legislators, Customers, Creditors and Competitors.

\section{Comparative influences on the formulation of the three classes of objectives}

A number of interesting conclusions can be drawn from the results discussed above. For ease of reference and comparison, the various interest groups and their respective mean influence figures are reproduced in Table 6, for each of the three classes of objectives. In terms of individual mean influence, the Chief Executive dominates the formulation of all three classes of objectives. It is interesting to note, that the next most important individual influence is from the Directors for the formulation of participant and performance objectives, but that Divisional Managers play the next dominant role after the Chief Executive in the formulation of strategic objectives.

Factor analysis was used to reduce the large number of individual influences to form a few groups or factors for each of the three classes of objectives. The various combined groups formed by the factor analyses are shown together in Table 7, for comparison and ease of reference. The factor analyses yielded results which appeared to provide a simple validation of the concept of three basic types of objectives. A rough interpretation by inspection of the interest groups formed by the factor loadings indicated the various group influences for each of the three classes of objectives. In the case of the 'participant' objectives, the strongest group influence comprising the 
Table 6 Comparative mean influences of individual interest groups on the formulation of the three classes of objectives

\begin{tabular}{|c|c|c|c|}
\hline Interest groups & $\begin{array}{c}\text { Participant } \\
\text { objectives }\end{array}$ & $\begin{array}{c}\text { Strategic } \\
\text { objectives }\end{array}$ & $\begin{array}{l}\text { Performance } \\
\text { objectives }\end{array}$ \\
\hline \multicolumn{4}{|l|}{ Internal groups: } \\
\hline $\begin{array}{l}\text { Shareholders } \\
\text { - Directors } \\
\text { - Chief executive } \\
\text { - Divisional } \\
\text { management } \\
\text { - Departmental } \\
\text { management } \\
\text { - Employees }\end{array}$ & $\begin{array}{l}2,01(8)^{*} \\
3,04(2) \\
3,73(1) \\
3,02(3) \\
2,48(6) \\
1,81(9)\end{array}$ & $\begin{array}{l}1,63(8) \\
2,80(5) \\
3,66(1) \\
3,23(2) \\
2,53(6) \\
1,55(9)\end{array}$ & $\begin{array}{l}2,38(6) \\
3,26(2) \\
3,79(1) \\
3,06(3) \\
2,39(5) \\
1,59(10)\end{array}$ \\
\hline $\begin{array}{l}\text { External groups: } \\
\text { - Government legis- } \\
\text { lators } \\
\text { - Customers } \\
\text { - Creditors } \\
\text { - Competitors }\end{array}$ & $\begin{array}{ll}2,34 & (7) \\
2,68 & (5) \\
1,55 & (10) \\
2,71 & (4)\end{array}$ & $\begin{array}{c}2,05(7) \\
3,11(3) \\
1,40(10) \\
2,98(4)\end{array}$ & $\begin{array}{ll}2,07 & (8) \\
2,31 & (7) \\
1,59 & (9) \\
2,40 & (4)\end{array}$ \\
\hline
\end{tabular}

- The ranked order of influence is shown by the number in parentheses behind each mean influence figure.

Chief Executive, Divisional and Departmental Managements and Employees, was found to be in harmony with the definition of that type of objective, that is, concern for and by those operating the company. The next influence came from the group comprising the Shareholders and Directors, while the final influence emanated from the external groups. When it came to 'strategic' objectives, the strongest group influence came from the key decision and policy-making group comprising the shareholders, Directors and Chief Executive as could be expected for the formulation of this type of objective. The second influence came from the expected Customers, Creditors and Competitors who have a direct bearing on the organization's product/market stance. The third influence in this case came from the middle and lower management, that is, Divisional Management, Departmental Management and Employees. In the 'performance' type objective, the strongest of all influences was found in the key decision and policy-making group comprising the Shareholders, Directors and Chief Executive as could be expected again for this critical form of objective. The second influence came from the group comprising middle and lower management, that is Divisional Management, Departmental Management and Employees. The weakest influence for this form of objectives was the external groups comprising Government Legislators, Customers, Creditors and Competitors.

Of particular interest, in the comparative factor groupings shown in Table 7, is the changing role of the Chief Executive
Table 7 Comparative factor groupings of the in. terest groups on the formulation of the three classes of objectives

\begin{tabular}{|c|c|c|c|}
\hline Factor & $\begin{array}{l}\text { Participant } \\
\text { objectives }\end{array}$ & $\begin{array}{l}\text { Strategic } \\
\text { objectives }\end{array}$ & $\begin{array}{l}\text { Performance } \\
\text { objectives }\end{array}$ \\
\hline \multirow{4}{*}{1} & Chief Executive & $\begin{array}{l}\text { Divisional } \\
\text { management }\end{array}$ & $\begin{array}{c}\text { Divisional } \\
\text { management }\end{array}$ \\
\hline & $\begin{array}{l}\text { Divisional } \\
\text { management }\end{array}$ & $\begin{array}{l}\text { Departmental } \\
\text { management }\end{array}$ & $\begin{array}{l}\text { Departmental } \\
\text { management }\end{array}$ \\
\hline & $\begin{array}{l}\text { Departmental } \\
\text { management }\end{array}$ & Employees & Employees \\
\hline & $\begin{array}{l}\text { Employees } \\
\text { (Mean 2,76) }\end{array}$ & (Mean 2,44) & (Mean 2,34) \\
\hline \multirow{5}{*}{2} & $\begin{array}{l}\text { Government } \\
\text { Legislators }\end{array}$ & Customers & $\begin{array}{l}\text { Government } \\
\text { Legislators }\end{array}$ \\
\hline & Customers & Creditors & Customers \\
\hline & Creditors & Competitors & Creditors \\
\hline & Competitors & & Competitors \\
\hline & (Mean 2,32) & (Mean 2,50) & (Mean 2,09) \\
\hline \multirow{3}{*}{3} & Shareholders & Shareholders & Directors \\
\hline & Directors & Directors & Shareholders \\
\hline & (Mean 2,53) & $\begin{array}{l}\text { Chief executive } \\
\text { (Mean 2,70) }\end{array}$ & $\begin{array}{c}\text { Chief executive } \\
\text { (Mean 3,14) }\end{array}$ \\
\hline
\end{tabular}

in the formulation of the three classes of objectives. This tabulation clearly reveals the conoept of the 'man-in-the-middle' role of the Chief Executive, that is, the man between his company executives and the board of directors. It can be seen from the table that the Chief Executive works with his company executives for the formulation of 'participant' type objectives but goes with the shareholders and directors when it comes to the formulation of 'strategic' and 'performance' type objectives.

\section{References}

Lorsch, J.W. \& Allen III, S.A. 1973. Managing Diversity and Interdependence. Ist Edition. Boston: Harvard University, Graduate School of Business Administration, Division of Research, 265 p.

Lorsch, J.W. \& Lawrence, P.R. 1970. Studies in Organisation Design. 1st Edition. Homewood, Illinois: Richard D. Irwin, Inc. and Georgetown, Ontario: The Dorsey Press, Irwin Dorsey Limited. February, $196 \mathrm{p}$.

Tukey, J.W. 1969. 'Analysing Data: Sanctification or Detective Work?' Amer. Psychol., vol. 24, 8391.

Woodburn, T.L. 1979. Corporate Strategic Planning in South African Organizations. Johannesburg: Unpublished Doctoral Thesis, University of the Witwatersrand. $384 \mathrm{p}$. 